\title{
Anticancer activities of phenolic compounds from Moringa oleifera leaves: in vitro and in silico mechanistic study
}

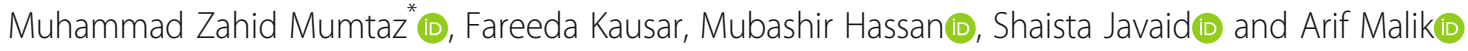

\begin{abstract}
Background: Moringa oleifera is a common vegetable in many countries since ancient times, possesses numerous phenolic compounds having a wide array of biological activities. It possesses anticancer activity that can be used to develop new drugs for treatment of various types of cancers. The current study was conducted to evaluate the composition of phenolic compounds and in vitro and in silico anticancer activities of $M$. oleifera leaves extracts. The leaves of M. oleifera were subjected to extraction for solvent fraction using n-hexane, chloroform, ethyl acetate, butanol, and aqueous solvents. The solvent fractions were tested for anticancer activity in vitro against Hela cancer cell line and screened for phenolic compounds through reversed-phase high-performance liquid chromatography. The molecular docking approach was employed to check binding conformations of phytochemicals against the target protein.
\end{abstract}

Result: The result revealed that all the solvent fractions possess in vitro anticancer activity against Hela cancer cell line. The $\mathrm{n}$-hexane fraction showed a 50\% reduction in Hela cancer cell viability at $416 \mu \mathrm{g} \mathrm{mL}^{-1}$ as compared to control. The extracts of solvent-fraction contained 10 phenolic compounds viz. quercetin, gallic acid, sinapic acid, vanillic acid, 4-hydroxy-3-methoxy benzoic acid, p-coumaric acid, m-coumaric acid, 4-hydroxy-3-methoxy cinnamic acid, caffeic acid, and syringic acid. Molecular docking studies revealed that the ligands bind within the active site of target protein have good binding energy values.

Conclusion: This study shows that M. oleifera leaves may have the potential to inhibit cancer cell growth and improving human health in addition to food ingredient innovations. Based on in vitro and in silico results, the phytochemicals from M. oleifera leaves can be used as leading drugs to treat cancer.

Keywords: Anticancer activity, Hela cancer line, Molecular docking, Moringa oleifera, Phenolic acids, Solvent fractions

\section{Background}

Medicinal plants are the richest resource of natural compounds having a wide range of applications for the wellbeing of human population. In the modern age, the dependence of humans on plants for the majority of commercial products including pharmaceutical, healthcare, food, beverages, textiles, cosmetics, and aromas is being obtained from plants. Therefore, plants are and will

\footnotetext{
*Correspondence: zahidses@gmail.com

Institute of Molecular Biology and Biotechnology, The University of Lahore, Main Campus, Lahore 54000, Pakistan
}

\section{Springer Open}

remain economically, industrially, environmentally, spiritually, historically, and aesthetically important for survival, sustenance, and prosperity of life on Earth [1-4].

Moringa oleifera (MO) is the most commonly grown species that belongs to the monogeneric family: Moringaceae that is native to the Himalayan and subHimalayan areas cultivated throughout Pakistan, India, Afghanistan, Bangladesh, and other tropical and subtropical countries of the world $[5,6]$. The MO has been utilized for flowers, fruit, and leaves as a vegetable particularly in India and Pakistan and many other parts of

(c) The Author(s). 2021 Open Access This article is licensed under a Creative Commons Attribution 4.0 International License, which permits use, sharing, adaptation, distribution and reproduction in any medium or format, as long as you give appropriate credit to the original author(s) and the source, provide a link to the Creative Commons licence, and indicate if changes were made. The images or other third party material in this article are included in the article's Creative Commons licence, unless indicated otherwise in a credit line to the material. If material is not included in the article's Creative Commons licence and your intended use is not permitted by statutory regulation or exceeds the permitted use, you will need to obtain permission directly from the copyright holder. To view a copy of this licence, visit http://creativecommons.org/licenses/by/4.0/. 
Asia and Africa [7-9]. In tropical areas of developing countries, MO is consumed by livestock as a forage, moringa micronutrient liquid, natural anthelmintic, and adjuvant against endemic diseases [5]. In many countries, roots, leaves, flowers, and seeds of $\mathrm{MO}$ are used in folk medicine for ailments and treatment of arthritis, asthma, blood pressure, body pain, cough, diabetes, diarrhea, dropsy, epilepsy, fever, headaches, hysteria, irritations, paralytic, skin infection, sores, tumors, weakness, wound, and employed as emmenagogues, expectorants, and mild diuretics, etc. [10-12]. They are of pungent taste and promote digestion [13]. The MO is a wellknown miracle tree enriched with important minerals (calcium, potassium, zinc, magnesium, iron, and copper), vitamins (vitamin $\mathrm{A}, \mathrm{B}, \mathrm{C}, \mathrm{D}$, and $\mathrm{E}$ ), carbohydrate, crude protein, ash, sugar, fat, glutelin, albumin, and globulins which can be used by doctors, nutritionists, and community health cautious persons to cure illness [5, 14-16].

The MO possess several phytochemicals such as ascorbates, beta-sitosterol, carotenoids, flavonoids, kaempferol, moringine, omega fatty acids, phenolic, quercetin, tocopherols, and vanillin, that have various biological activities including antiatherosclerotic, anticancer, antidiabetic, anti-inflammatory, antimicrobial, antioxidant, antiulcer, antiviral, and immune-boosting [8, 17-23]. Among these phytochemicals, phenolic acids are the most abundant secondary metabolites of plants and are involved in many biological activities. They are of benzoic acid and cinnamic acid derivatives including caffeic, chlorogenic, coumaric, ferulic, gallic, and quinic acids, tannins, and many others having more than 8000 phenolic structure found in various fruits and vegetables [24, 25]. Prabakaran et al. [26] reported the presence of total phenolic and total flavonoids contents in leaves as compared to roots, barks, and flower extracts of MO.

Cancer is the largest group of diseases causing death of 9.6 million people worldwide [27]. The most common type of cancer in females are breast, cervical, colorectal, lung, and thyroid cancers. Among them, cervical cancer is the fourth most leading cause of death in women and causing 270,000 deaths annually [28]. It is well known that $74 \%$ of anticancer medicines are being derived from various plant species [29]. The MO leaves extracts showed remarkable effects against various cancerous cells [30]. Balamurugan et al. [31] reported the anticancer effect of MO leaf extracts against hepatic cancer cell line (HepG2). The phytochemicals showed a dynamic role in treatment and prevention of cancer by hindering cancer cells through activating hormones and enzymes, stimulation of DNA repair mechanism, enhancing the production of protective enzymes that induce antioxidant action and enhance immunity [32-34]. Because of these facts, the current study was conducted to evaluate the composition of phenolic compounds and anticancer activities of different solvent fractions of $\mathrm{MO}$ leaves extracts. To achieve the purpose of the current study, solvent fractions of MO leaves extracts were prepared using n-hexane, ethyl acetate, butanol, and water to their polarities. For phenolic compounds, various solventfractions (SF) were analyzed using reversed-phase highperformance liquid chromatography. The SF extracts were analyzed on Hela cancer cell lines for their antiproliferative activity.

\section{Methods}

\subsection{Plant material}

Moringa oleifera (MO) leaves were collected in June (three months after spring season) from Baagh-e-Jinnah Park Lahore, Pakistan, and transported within $1 \mathrm{~h}$ to Plant Biotechnology Laboratory. Leaves were washed three times with distilled water to remove unnecessary material and dust particles and dried under shade for a month. Leaves specimen were identified by consulting medicinal plant name services (https://www.kew.org/ mpns) and by comparing herbarium specimens for taxonomic and botanical authentication. The specimen was deposited within the institute having voucher specimen numbers 845 was assigned. The dried leaves were ground into a fine powder using a mortar/pestle to maximize the extraction yield and sieved through 0.3 $\mathrm{mm}$ mesh size. The pulverized fine powered $(100 \mathrm{~g} \mathrm{w} / \mathrm{v})$ was extracted with $80 \%$ methanol (Sigma-Aldrich, USA) $(200 \mathrm{~mL} \mathrm{v} / \mathrm{v})$ at $25^{\circ} \mathrm{C}$ for three times to retrieve more of the active compounds. After $90 \mathrm{~min}$, the percolated extract was concentrated by a rotary vacuum evaporator (V700, BUCHI AG, Switzerland). The extracted solution was filtered twice with Whatman No. 1 filtering paper to remove insoluble matrices. Then, the filtrate was successively partitioned using a solvent of grade polarities: $\mathrm{n}$ hexane (Daejung, Korea), chloroform (Merk, Germany), ethyl acetate (Daejung, Korea), butanol (Merk, Germany), and distilled water by using orbital shaker at $200 \mathrm{rpm}$ for overnight [35]. The solvents were removed from crude leaves extract under reduced pressure using a rotary evaporator (Hei-VAP, Heidolph, Germany) and vacuum pump with the refrigerated circulator.

\subsection{Anticancer activity}

The anticancer activity of MO leaves extracts was evaluated through 3-(4,5-dimethylthiazol-2-yl)-2,5-diphenyltetrazolium bromide tetrazolium (MTT) reduction assay $[36,37]$. The sample of each extract was diluted in Dimethyl sulfoxide (DMSO) to obtain a concentration of $26,52,104,206$, and $416 \mu \mathrm{g} \mathrm{mL}^{-1}$ by microdilution assay [38]. The cytotoxicity assay was performed by incubating samples in 96-well plates containing Hela cancer cell lines (American Type Culture Collection, ATCC) maintained in a culture medium made of Dulbecco's modified 
Eagle's medium (DMEM) (Caisson Labs, USA) with 2 mM L-glutamine (Lonza) augmented with $10 \%$ fetal bovine serums (Sigma-Aldrich, USA), 100 units of antibiotics (penicillin; Sigma-Aldrich, USA). The cells were cultured in the medium up to the log phase under $5 \%$ $\mathrm{CO}_{2}, 37{ }^{\circ} \mathrm{C}$ temperature, $7.4 \mathrm{pH}$, and $90 \%$ humidity conditions. The MTT solution was prepared by using 2.5 mg MTT and extraction buffer (prepared by using $20 \%$ sodium dodecyl sulfate and 50\% DMSO in distilled water). The $0.2 \mathrm{~mL}$ of DMEM medium was taken in 5000 cells/well in 96-well plates and incubated at $37{ }^{\circ} \mathrm{C}$ for $24 \mathrm{~h}$. Then, the medium was aspirated at $37{ }^{\circ} \mathrm{C}$ and dried on tissue paper. Further, $200 \mu \mathrm{L}$ of samples, $25 \mu \mathrm{l}$ of MTT solution, and $100 \mu \mathrm{L}$ extraction buffer were added in each well and incubated at $37{ }^{\circ} \mathrm{C}$ for $24 \mathrm{~h}$. The extraction buffer was used as a blank. The optical density was taken at $570 \mathrm{~nm}$ using enzyme-linked immunosorbent assay (ELISA) reader (PR4100, BioRad, USA). The relative cell viability was calculated by adopting a formula reported by Bendale et al. [39]. The data were statistically analyzed by SPSS 21.0 package program for Windows. Statistical analysis was carried out by employing a one-way analysis of variance (ANOVA) and the least significant difference (LSD) multiple comparison test at a $5 \%$ level of probability [40]. Values were reported as a mean of three replications along with standard error.

\subsection{Determination of phenolic compounds through reversed-phase high-performance liquid chromatography (RP-HPLC)}

The phenolic compound in different solvent extract samples was quantified through reversed-phase high-performance liquid chromatography (RPHPLC). The samples were prepared through take 25 mg of crude extract in $5 \mathrm{~mL}$ of $\mathrm{HCl}(6 \mathrm{M}), 12 \mathrm{~mL}$ of methanol and $8 \mathrm{~mL}$ of distilled water and incubated at $90{ }^{\circ} \mathrm{C}$ for $2 \mathrm{~h}$. After incubation, the mixture was filtered with a $0.2-\mathrm{mm}$ MF-Millipore ${ }^{\mathrm{TM}}$ membrane filter (Merck, Germany) and injected in HPLC. The HPLC separation was done using the HPLC system with column 20RBAX ECLIPSE, XDB-C18, $(5 \mu \mathrm{m}: 4.6 \times 150 \mathrm{~mm}$, Agilent, USA) and UV-VIS spectra-focus detector. The isocratic mobile phase (tetrahydrofuran, acetonitrile, and $0.05 \%$ phosphoric acid solution in the ratio of $20: 3: 77 \mathrm{v} / \mathrm{v} /$ v) was injected at a flow rate of $1 \mathrm{~mL} \mathrm{~min}^{-1}$. Before use, the mobile phase was filtered through $0.2 \mathrm{~mm}$ MF-Millipore ${ }^{\mathrm{TM}}$ membrane filters and degassed by sonication in an ultrasonic bath. The detection wavelength was set at $280 \mathrm{~nm}$ and the column temperature was maintained at room temperature with an injection volume of $10 \mu \mathrm{L}$.
2.4 Retrieval of protein structure and designing of ligands The Bcl-2-associated X (BAX) protein human (Homo sapiens) was accessed from Protein Data Bank (PDB) having PDBID: 1 F16 (https://www.rcsb.org/structure/1F16) and utilized as a target molecule. The selected protein further undergoes energy-minimization through UCSF Chimera v1.12 at 1000 steepest and 1000 conjugate gradient runs with Amber force field parameters [41]. Based on in vitro analysis, four chemical compounds were selected for the computational study. Four chemical compounds quercetin, gallic acid, $p$-coumaric acid, and 4hydroxy 3-methoxy cinnamic acid were retrieved in PDB through sketching in ChemDraw [42]. The refinement and gematory optimization of these selected compounds were confirmed by Chem3D Pro [43] and UCSF Chimera v1.12, respectively. the molecular properties of selected compounds were predicted through an online tool such as Molsoft (http://molsoft.com/mprop/)

\subsection{Molecular docking}

To check the binding behavior of quercetin, gallic acid, p-coumaric acid and 4-hydroxy 3-methoxy cinnamic acid against BAX protein, a computational docking approach was utilized through PyRx [44]. Initially, protein grid parameters were fixed in all three dimensions by taking a binding pocket as core-site. Finally, docking experiments were performed against the minimized phytocompounds and targeted proteins, separately using AutoDock-Vina [44]. The grid box values of selected center $x=39.86, y=25.22, z=38.88$ and size of $x=$ $36.17, y=40.50$, and $z=35.62$, respectively. The default exhaustiveness value $=8$ was also used for better interaction behavior of compounds against target protein in docking. The generated docked complexes were analyzed based on binding energy values as interactive behaviors (hydrogen/hydrophobic interactions) of ligands. Furthermore, the binding conformation within the active site of the target protein was also observed for all three ligands against best-selected proteins. The graphical depiction of docked complexes was investigated and visualized by UCSF Chimera v1.12. and Discovery Studio 2017.

\section{Results}

\subsection{Solvent-fractions of $M$. oleifera leaves showed} anticancer activity in vitro

The cytotoxicity of different SF of MO leaves against Hela cancer cells line was performed using MTT assay. A range of different doses $\left(26,52,104,208\right.$, and $\left.416 \mu \mathrm{g} \mathrm{mL}^{-1}\right)$ of five SF (n-hexane, chloroform, butanol, ethyl acetate, and water) of MO leaves was evaluated for their potential anticancer activity. The data were collected in terms of percent cell viability of cancer cells given in Fig. 1 and percent inhibition in cancer cells given in Table 1. Among 


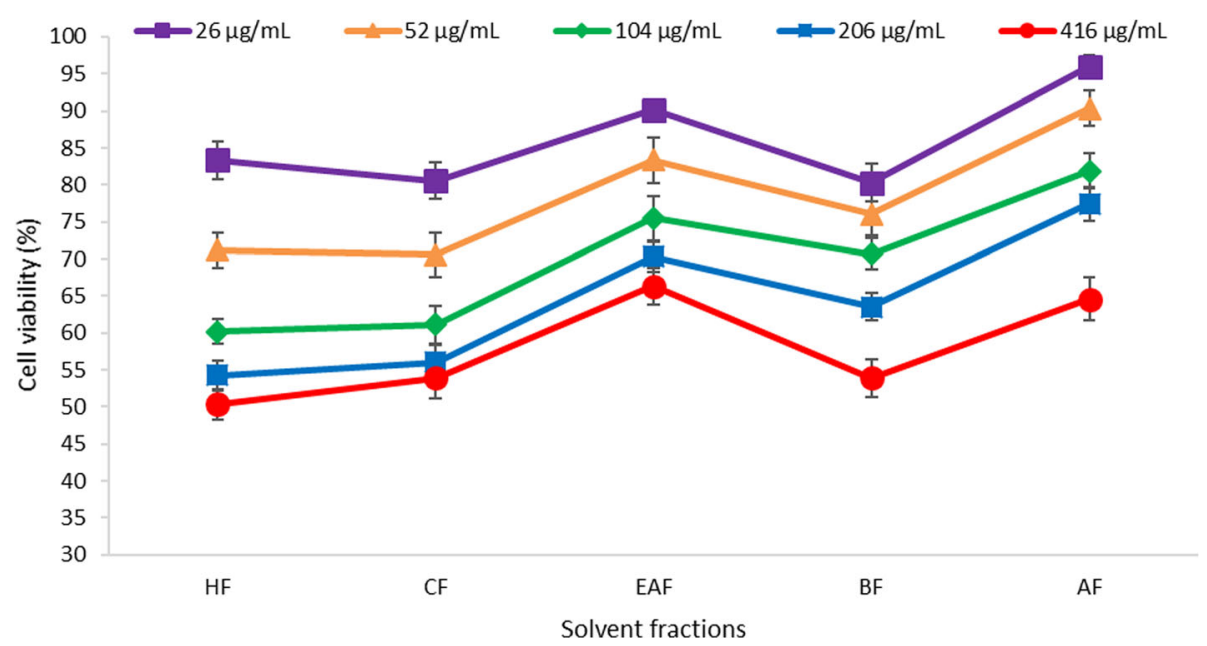

Fig. 1 Cytotoxic effect of Moringa oleifera leaves extracts of various solvents viz. n-hexane, chloroform, ethyl acetate, butanol, and water on Hela cancer line. Data of relative cell viability represented as means \pm error bars of three replications at $p \leq 0.05$ versus control which give $100 \%$ cell viability

SF, chloroform-fraction (CF) followed by n-hexanefraction (HF) and butanol-faction (BF) showed their highest anticancer activities in terms of cell viability and inhibition in cancer cells. While aqueous-fraction (AF) followed by ethyl-acetate fraction (EAF) was lowest to demonstrate their anticancer activity. The inverse relationship was found between the increase in the dose of SF and cancer cell viability (Fig. 1), while, there was a direct relationship between the increase in the dose of SF and inhibitions in cancer cell growth (Table 1). Various doses of SF showed variable anticancer activity with maximum activity was recorded with the application of $416 \mu \mathrm{g} \mathrm{mL} \mathrm{m}^{-1}$ of all tested $\mathrm{SF}$, while, $26 \mu \mathrm{g} \mathrm{mL} \mathrm{m}^{-1}$ of tested SF showed minimum anticancer activity. Application of $416 \mu \mathrm{g} \mathrm{mL} \mathrm{L}^{-1}$ of $\mathrm{HF}$ showed maximum inhibition in cancer cells up to $50 \%$ with $50 \%$ cell viability followed by CF and BF both having $46 \%$ inhibition in cancer cells growth and 54\% cancer cell viability. While EAF followed by AF at $416 \mu \mathrm{g} \mathrm{mL}^{-1}$ showed the lowest inhibition in cancer cells up to 34 and 35\%, respectively, with 66 and $65 \%$, respectively, of cancer cells viability.

Table 1 Hela cancer cells inhibition due to the application of various solvent fractions of Moringa oleifera

\begin{tabular}{llllll}
\hline Doses & HF & CF & EAF & BF & AF \\
& \multicolumn{5}{l}{ Hela cancer cells inhibition $(\% \pm$ SE) } \\
\hline $26 \mu \mathrm{g} \mathrm{mL}^{-1}$ & $17 \pm 2.61$ & $19 \pm 3.38$ & $10 \pm 1.59$ & $20 \pm 2.07$ & $4 \pm 2.01$ \\
$52 \mu \mathrm{mL}^{-1}$ & $29 \pm 3.54$ & $30 \pm 3.93$ & $17 \pm 3.52$ & $24 \pm 2.24$ & $10 \pm 2.83$ \\
$104 \mu \mathrm{g} \mathrm{mL}^{-1}$ & $33 \pm 1.34$ & $39 \pm 2.06$ & $25 \pm 3.09$ & $29 \pm 2.08$ & $18 \pm 2.46$ \\
$206 \mu \mathrm{gL}^{-1}$ & $46 \pm 2.52$ & $44 \pm 2.94$ & $30 \pm 3.64$ & $37 \pm 2.83$ & $23 \pm 1.55$ \\
$416 \mathrm{mg} \mathrm{mL}^{-1}$ & $50 \pm 1.53$ & $46 \pm 2.34$ & $34 \pm 2.33$ & $46 \pm 2.25$ & $35 \pm 2.91$ \\
\hline
\end{tabular}

3.2 Phenolic acids quantification from solvent-fractions of M. oleifera leaves through RP-HPLC

Reversed phased-high performance liquid chromatography (RP-HPLC) was employed for the identification and quantification of phenolic acids present in the SF of MO leaves. Results revealed that 10 phenolic compounds: quercetin, gallic acid, sinapic acid, vanillic acid, 4-hydroxy benzoic acid, $p$ coumaric acid, $m$-coumaric acid, 4-hydroxy-3-methoxy cinnamic acid, caffeic acid, and syringic acid were identified and quantified in $\mathrm{HF}, \mathrm{CF}, \mathrm{EAF}, \mathrm{BF}$, and $\mathrm{AF}$ of MO leaves. The amounts of phenolic acids present in SF of MO leaves are given in Table 2 and their chemical structural formulas are provided in Fig. 2. The value of total phenolic contents (TPC) varied and ranged from 5.81 to $24.68 \mathrm{mg} \mathrm{g}^{-1}$ of dry matter. Out of all of SF, BF had the highest TPC (24.68 mg $\mathrm{g}^{-1}$ of dry matter). Following BF, AF $\left(21.55 \mathrm{mg} \mathrm{g}^{-1}\right.$ of dry matter) and CF (16.11 $\mathrm{mg} \mathrm{g}^{-1}$ of dry matter) exhibited the highest TPC. While EAF extracted lowest amount of TPC (5.81 $\mathrm{mg} \mathrm{g}^{-1}$ of dry matter). The quercetin, gallic acid, and $p$-coumaric acid were detected in all the tested SF with highest contents of quercetin in AF $\left(4.71 \pm 0.01 \mathrm{mg} \mathrm{g}^{-1}\right.$ of dry matter) and gallic acid (10.18 $\pm 0.03 \mathrm{mg} \mathrm{g}^{-1}$ of dry matter $)$ and $p$-coumaric acid $\left(10.18 \pm 0.03 \mathrm{mg} \mathrm{g}^{-1}\right.$ of dry matter) in BF. The 4-hydroxy-3-methoxy cinnamic acid was also detected in all the tested SF except HF having highest contents of $7.81 \pm 0.01 \mathrm{mg} \mathrm{g}^{-1}$ of dry matter in BF. The ferulic, sinapic, and syringic acids were detected from HF and AF. While vanillic, $m$-coumaric, and caffeic acid were only detected in a single fraction of $\mathrm{HF}, \mathrm{AF}$, and EAF, respectively. However, the extracted concentration of TPC $\left(24.7 \mathrm{mg} \mathrm{g}^{-1}\right)$ was higher in BF that showed gallic acid $\left(10.2 \mathrm{mg} \mathrm{g}^{-1}\right)$, 4-hydro 3methoxy cinnamic acid $\left(7.8 \mathrm{mg} \mathrm{g}^{-1}\right)$ and $p$-coumaric acid $\left(5.5 \mathrm{mg} \mathrm{g}^{-1}\right)$ as major metabolites. Followed by 
Table 2 Phenolic compounds in solvent extract fraction of Moringa oleifera analyzed through reversed-phase high-performance liquid chromatography (RP-HPLC)

\begin{tabular}{|c|c|c|c|c|c|}
\hline \multirow{2}{*}{ Phenolic acids } & $\mathrm{HF}$ & $\mathrm{CF}$ & EAF & $\mathrm{BF}$ & AF \\
\hline & \multicolumn{5}{|c|}{$\mathrm{mg} \mathrm{g}^{-1}$ of dry matter } \\
\hline Quercetin & $0.17 \pm 0.02$ & $0.97 \pm 0.02$ & $0.19 \pm 0.02$ & $1.22 \pm 0.02$ & $4.71 \pm 0.01$ \\
\hline Gallic acid & $0.64 \pm 0.01$ & $8.77 \pm 0.03$ & $0.19 \pm 0.01$ & $10.18 \pm 0.03$ & $2.74 \pm 0.01$ \\
\hline Sinapic acid & $0.86 \pm 0.03$ & ND & ND & ND & $0.37 \pm 0.01$ \\
\hline 4-Hydroxy benzoic acid & $2.43 \pm 0.03$ & $2.69 \pm 0.01$ & ND & ND & $5.31 \pm 0.01$ \\
\hline p-Coumaric acid & $0.48 \pm 0.03$ & $0.72 \pm 0.02$ & $1.25 \pm 0.01$ & $5.47 \pm 0.03$ & $0.43 \pm 0.02$ \\
\hline m-Coumaric acid & ND & ND & ND & ND & $0.715 \pm 0.02$ \\
\hline 4-hydroxy 3-methoxy cinnamic acid & ND & $2.96 \pm 0.01$ & $2.05 \pm 0.01$ & $7.81 \pm 0.01$ & $1.21 \pm 0.01$ \\
\hline Caffeic acid & ND & ND & $2.13 \pm 0.02$ & ND & ND \\
\hline Syringic acid & $0.33 \pm 0.02$ & ND & ND & ND & $2.76 \pm 0.02$ \\
\hline Total phenolic acids & 7.92 & 16.11 & 5.81 & 24.68 & 21.17 \\
\hline
\end{tabular}

BF, CF extracted maximum TPC concentration (16.1 $\mathrm{mg} \mathrm{g}^{-1}$ ) having gallic acid (16.1 $\left.\mathrm{mg} \mathrm{g}^{-1}\right)$ as a major metabolite. The HF was able to extract $7.9 \mathrm{mg} \mathrm{g}^{-1}$ of TPC concentration which tells us the possibility of other phytochemical responsible for its excellent anticancer activity.

\subsection{Chemoinformatics analysis}

The chemo-informatics properties were evaluated by computational approaches to check the basic biochemical properties. Results exposed that all compounds quercetin, gallic acid, $p$-coumaric acid, and 4-hydroxy 3methoxy cinnamic acid have better-predicted values of<smiles>COc1cc(C(=O)O)ccc1O</smiles> 
molecular weight $(\mathrm{g} / \mathrm{mol})$. The molecular weight $(\mathrm{g} / \mathrm{mol})$ of all compounds was also comparable with standard value $(<5000 \mathrm{~g} / \mathrm{mol})$. Moreover, the Lipinski's rule of five (RO5) results showed that compounds (quercetin, gallic acid, p-coumaric acid, and 4-hydroxy 3-methoxy cinnamic acid) possessed good hydrogen bond acceptors (HBA) and hydrogen bond donar (HBD) values which significantly justified their drug-like behavior. The overall predicted results values of all compounds are mentioned in Table 3.

\subsection{Docking energy evaluation of selected compounds}

To predict the best conformational position within the active region of the target protein, the selected compounds were docked against selected targeted protein. All the generated docked complexes were examined based on minimum energy values $(\mathrm{Kcal} / \mathrm{mol})$ and bonding interaction pattern (hydrogen, hydrophobic, and electrostatic). The quercetin possesses -7.80 whereas other, gallic acid, p-coumaric acid, and 4-hydroxy 3methoxy cinnamic acid exhibited - 5.8, - 5.6, and - 5.7 $\mathrm{Kcal} / \mathrm{mol}$, respectively. Docking results justified that compounds exhibited good docking energy values Kcal/ mol (Fig. 3).

\subsection{Binding conformations of phytocompounds}

The binding interaction behavior of selected compounds was evaluated based on hydrogen and hydrophobic interactions. Figure 4 showed that all four compounds were bound at the same conformations inside the binding pocket of the target protein. The ligands (quercetin, gallic acid, $p$-coumaric acid, and 4-hydroxy 3-methoxy cinnamic acid) were binds with different binding poses with little conformational configurations.

\subsection{Hydrogen and hydrophobic binding analysis of docked complexes}

In gallic acid-BAX docking complex, four hydrogen bonds were observed at different residual positions such as Asp98, Asp99, Phe64, and Thr263 at different bind distance. The carboxylic group of gallic acid forms two hydrogen bonds 2.13 and $2.61 \AA$. The hydroxyl groups at meta and para positions in gallic acid form hydrogen bonds having bond length 3.00 and $2.21 \AA$ at Phe64 and Thr263, respectively (Fig. 5). In $p$-coumaric acid-BAX docking complex, a couple of hydrophobic interactions were observed at Leu62 and Pro63 with different conformation positions. The hydroxyl groups in $p$-coumaric acid form two hydrophobic interactions with bond lengths 5.32 and $5.42 \AA$, respectively (Fig. 6).

In quercetin-BAX docking complex, three hydrogen bonds Gln190, Asp99, and Glu259. The hydroxyl groups in quercetin form three hydrogen bonds with bond distances 2.46, 2.30, and $2.56 \AA$, respectively (Fig. 7). Quercetin showed best docking energy values and good interaction behavior compared to all other compounds. In 4-hydroxy 3-methoxy cinnamic acid-BAX docking complex, two hydrogen bonds were observed at Glu259 and Ile257 with bond distances 2.45 and $2.50 \AA$, respectively (Fig. 8).

\section{Discussion}

Moringa oleifera (MO) is a common vegetable plant in many Asian countries and is known as "the Miracle Tree" due to its uses in herbal medicine for treating over 300 various diseases [45]. Its leaves and pods possess numerous compounds with excellent health benefits that are being consumed by doctors, healers, nutritionists, and community persons to address under-nutrition and anemia conditions in children and infants $[15,46]$. The MO possesses numerous compounds with excellent health benefits. Keeping in view the therapeutic activity of MO, we postulated that SF of MO leaves could be effective in the treatment of cancer disease. To the best of our knowledge, this is the first study reporting anticancer activities by using various MO leaves SF based on polarities. We assessed the SF of MO leaves for the anticancer property against Hela (cervical) cancer cell line. Our prime aim was to obtain numerous phenolic contents of $\mathrm{MO}$ leaves partitioned using five solvent of grade polarities including hexane, chloroform, ethyl acetate, butanol, and aqueous. The RP-HPLC analyses of SF of MO leave revealed numerous phenolic compounds including 4-hydroxy 3-methoxy cinnamic, 4-

Table 3 Drug likeness analyses of phytocompounds

\begin{tabular}{lllll}
\hline Properties & Gallic acid & $\boldsymbol{p}$-Coumaric acid & Quercetin & 4-Hydroxy 3-methoxycinnamic acid \\
\hline Mass (g/mol) & 170 & 164 & 302 & 194 \\
Logp & 0.55 & 2.07 & 2.11 & 2.04 \\
HBA & 5 & 3 & 7 & 4 \\
HBD & 4 & 2 & 5 & 2 \\
PSA (A $\left.{ }^{2}\right)$ & 77 & 46 & 102 & 52 \\
RO5 violations & No & No & No & No \\
Drug Score & 0.07 & -0.74 & 0.93 & -0.44 \\
\hline
\end{tabular}




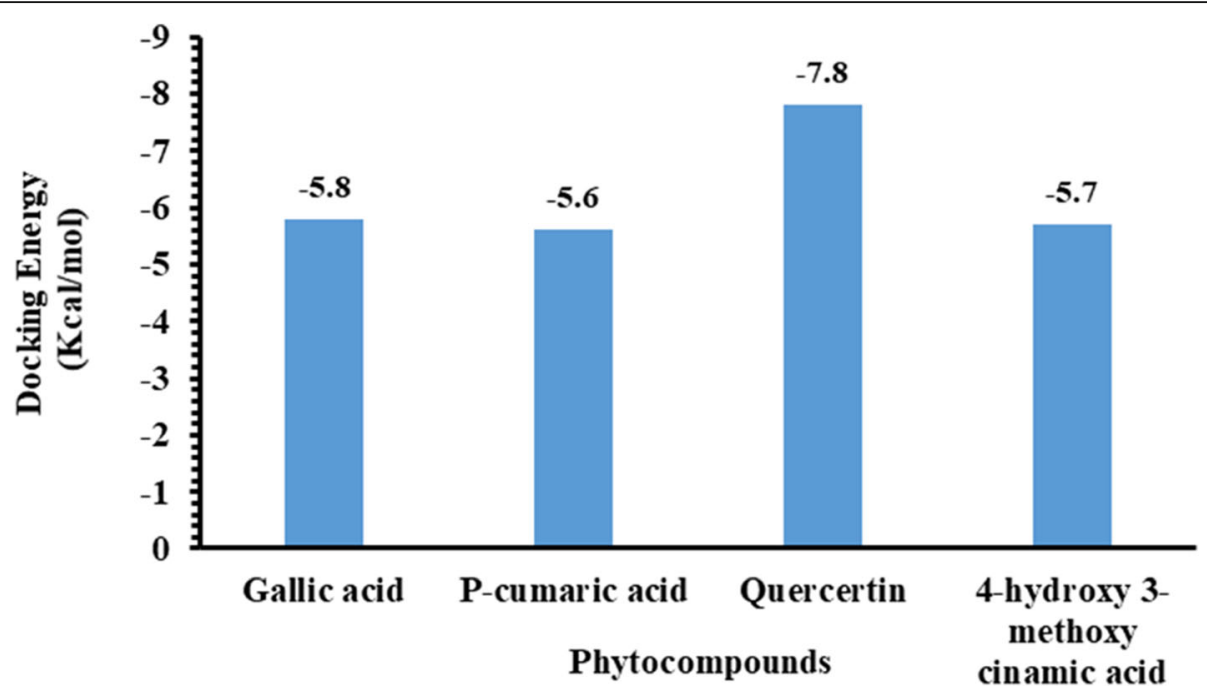

Fig. 3 Docking energy values of compounds

hydroxybenzoic, caffeic, ferulic, gallic, $m$-coumaric, $p$ coumaric, quercetin, sinapic, syringic, and vanillic acids in the chromatogram (Table 2).

In the present study, the anticancer activity by SF of MO leaves was observed in terms of cell viability in a dose depended manner. All the SF of MO leaves showed a significant reduction in Hela cancer cell viability. The concentration of SF and reduction in cell viability were directly proportional as increased concentration of SF showed maximum reduction in cell viability. A maximum reduction in cell viability was obtained from $\mathrm{HF}$ at $416 \mu \mathrm{g} \mathrm{mL}^{-1}$ which was non-significant to $\mathrm{CF}$ and $\mathrm{BF}$ (Fig. 6). Tiloke et al. [47] reported that plants exhibit anticancer potential by interfering with the signal transduction cascade that promotes cancer cell proliferation. The inhibition of cancer cell viability could be due to phenolic compounds especially eugenol [48], D-allose [49], and isopropyl isothiocyanate [50]. Eugenol plays a significant role in the apoptosis of breast cancer MDAMB231 cells through the overexpression of Bax protein [51]. Eugenol could also trigger apoptosis through the downregulation of E2F1/survivin in breast cancer cells [48]. In the present study, the decreased cell viability in Hela cancer cells could be due to the ability of SF of $\mathrm{MO}$ leaves to cause an increase in apoptosis through downregulation of E2F1 and upregulation of Bax protein. Phenolic compounds present in SF of MO leaves could also cause a reduction in cell viability through shutting down of cancer survival pathway including NF-K $\beta$ signaling cascade through downregulation of p 65 component. Jung [52] reported AF of MO leaves as a novel potential anticancer candidate that induced apoptosis in lung cancer cells. The current study opens new prospective research to elucidate the molecular mechanism

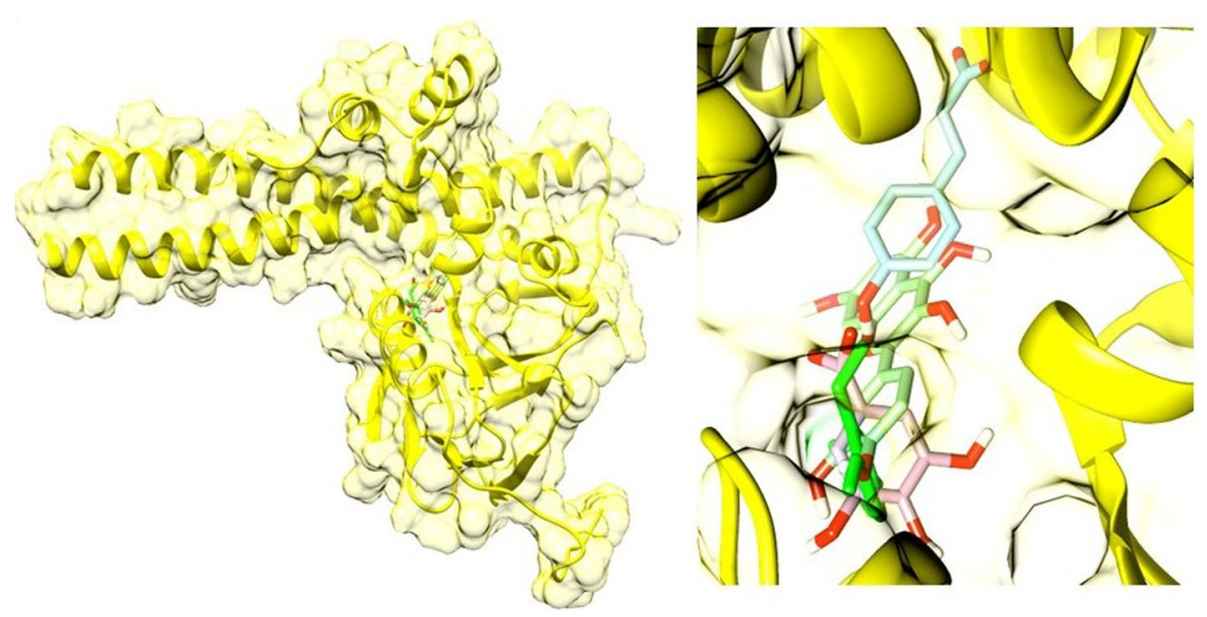

Fig. 4 Binding poses of ligands 


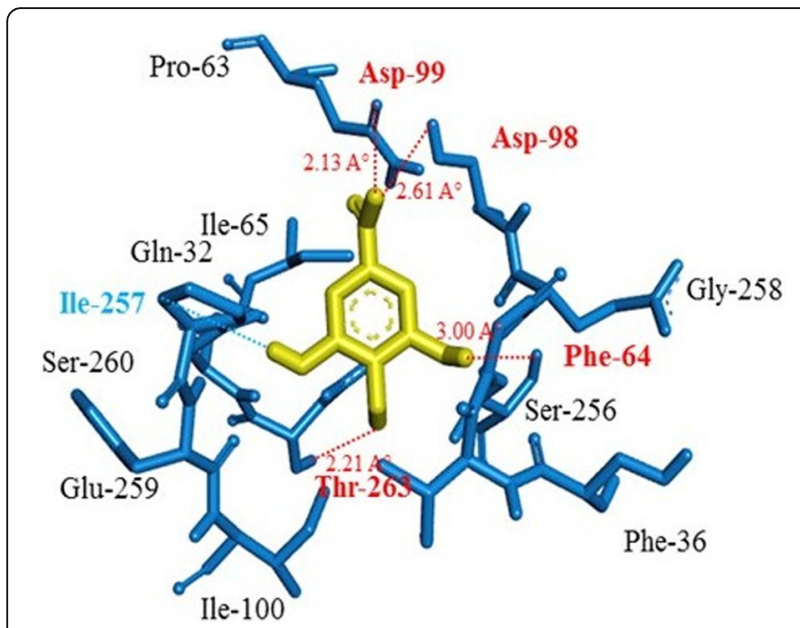

Fig. 5 Docking complexes of gallic acid-Bcl2-associated $X$ (BAX) protein

after treating with variable extracted concentration through SF of MO leaves. The future investigation needs to explore the expression of targeted protein P13K/AKT pathway and inhibition of phosphorylation of focal adhesion kinase (p-FAK) which is important in cell migration and cell invasion.

In the present study, SF of MO leaves was subjected to identification and quantification of phenolic acid

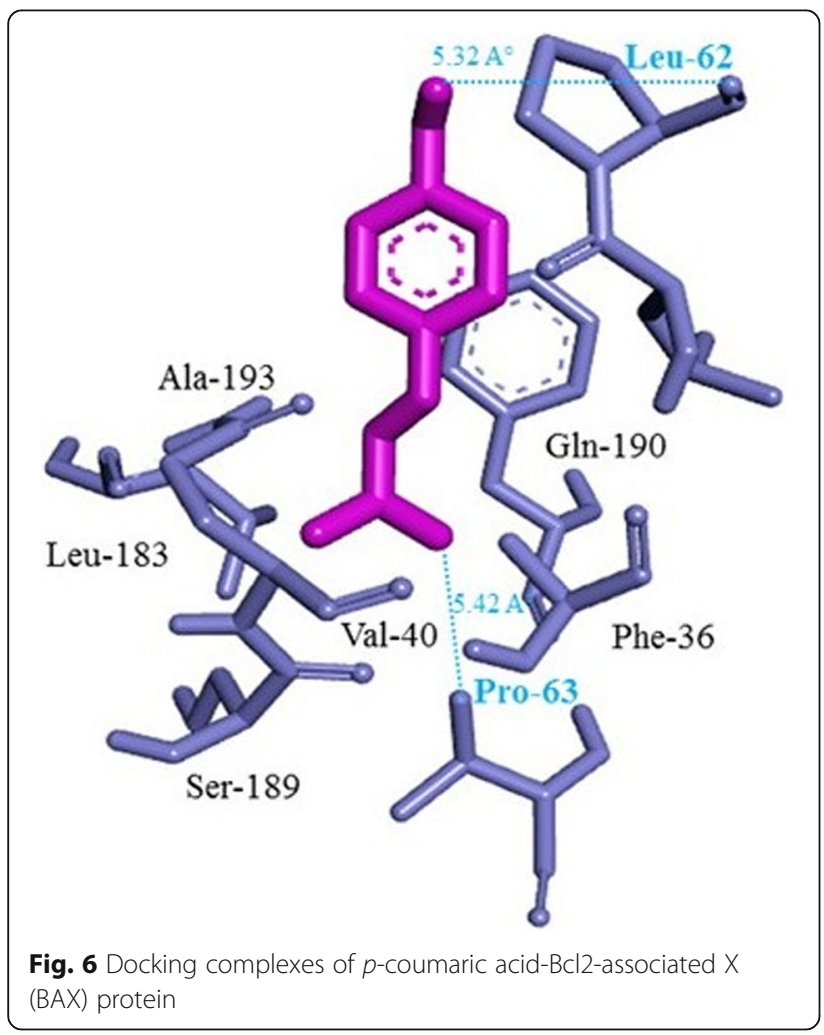

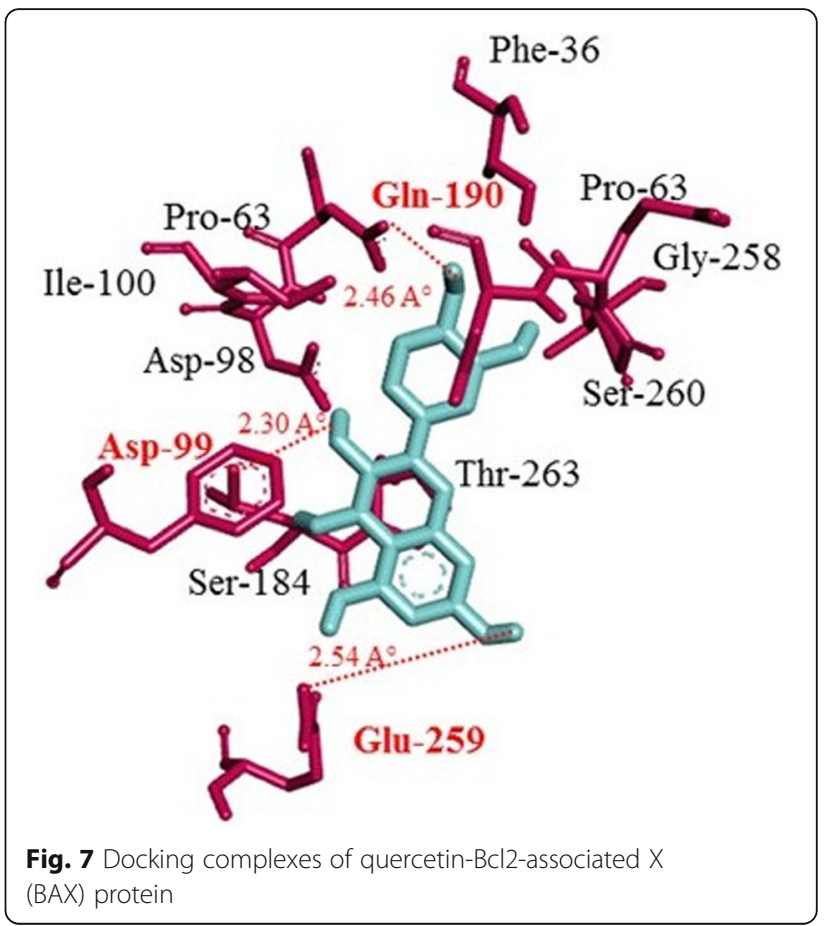

through RP-HPLC analysis. Phenolic compounds including quercetin, gallic acid, sinapic acid, vanillic acid, 4hydroxy benzoic acid, $p$-coumaric acid, $m$-coumaric acid, 4-hydroxy-3-methoxy cinnamic acid, caffeic acid, and syringic acid were quantified in various SF of MO leaves (Table 2). Highest TPC was obtained through BF followed by AF while EAF extracts lowest TPC. Among phenolic compounds, highest concentrations of gallic acid, 4-hydro 3-methoxy cinnamic acid, and $p$-coumaric acid were detected in BF of MO leaves. The AF possessed all the determined phenolic contents, while, phenolic compounds viz. m-coumaric acid, 4-hydroxy 3-

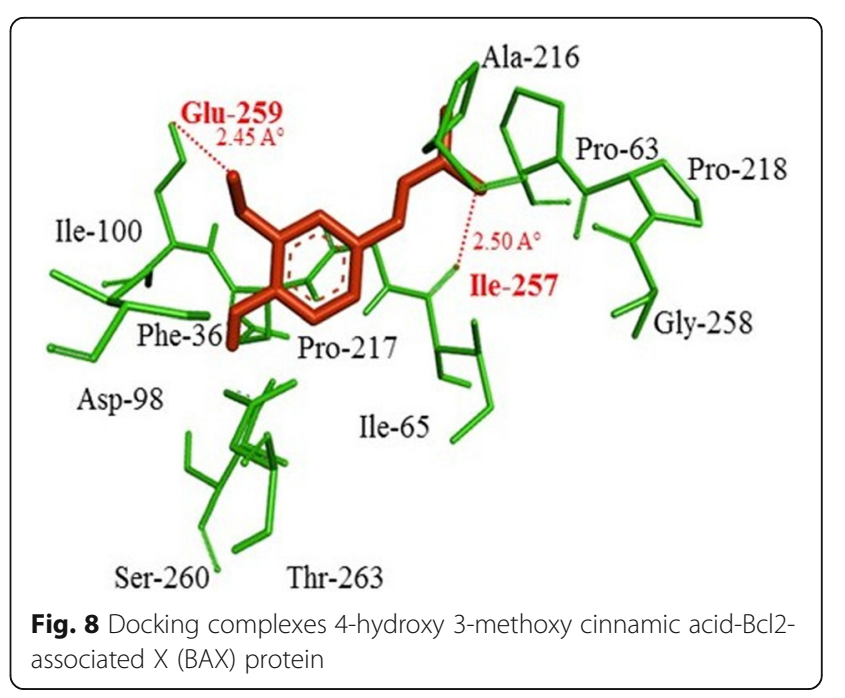


methoxy cinnamic acid, and caffeic acid were not present in HF. However, HF showed higher anticancer activity as compared to AF that may be due to the presence of other phytocompounds in higher concentrations. The derivatives of hydroxybenzoic and hydroxycinnamic acid extract in SF of MO leaves could have a possible role in the prevention and treatment of cancer as reported in various studies [18, 53]. Phenolic acid from plant extract could reduce tumor initiation through adapting various mechanism viz. inhibiting genotoxic molecules, hindering mutagens-transforming enzymes activity, regulating enzymes such as heme-containing phase I and carcinogen-detoxifying phase II enzymes [54-56]. In the present study, highest anticancer activity was obtained from HF followed by CF and BF. The detection of phenolic acid in BF supports the findings of anticancer activity as BF reported highest TPC; however, there must be some other phytocompounds in HF and $\mathrm{CF}$ that are maximizing their anticancer activity. The current study is suggesting the future investigation on quantification of other phytocompounds in HF and CF of $\mathrm{MO}$ leaves that can define their anticancer activity.

Based on in vitro results, four phenolic compounds including quercetin, gallic acid, $p$-coumaric acid, and 4hydroxy 3-methoxy cinnamic acid were selected to evaluate their chemo-informatics properties. The predicted results showed that compounds possessed good HBA and HBD values that significantly justified their drug-like behavior. In prior results, it has been observed that compounds with more HBA are more likely associated with poor absorption. However, there are plenty of examples available for RO5 violations amongst the existing drugs [57]. Furthermore, a molecular docking approach was utilized for the binding behavior of quercetin, gallic acid, $p$-coumaric acid, and 4-hydroxy 3methoxy cinnamic acid against BAX protein docking, and results justified that all compounds exhibited good docking energy values. Our generated results showed that selected compounds were bind at same conformations inside the binding pocket of target protein. Among selected phenolic compounds, quercetin showed best docking energy values and good interaction behavior compared to all other compounds.

\section{Conclusion}

The current study is performed to recognize the therapeutic effect of $M$. oleifera based compounds against cancer. The in vitro and in silico results showed that quercetin, gallic acid, p-coumaric acid, and 4-hydroxy 3methoxy cinnamic acid displayed potent anticancerous activity and good therapeutic potential against cancer. Based on the aforementioned results, it can be concluded that these phytochemicals could be used as leading drugs to treat cancer.

\section{Abbreviations}

MTT: 3-(4,5-dimethylthiazol-2-yl)-2,5-diphenyltetrazolium bromide; ATCC: American Type Culture Collection; ANOVA: Analysis of variance; AF: Aqueous-fraction; BAX: BCl-2-associated X; BF: Butanol-fraction;

CF: Chloroform-fraction; DMSO: Dimethyl sulfoxide; DMEM: Dulbecco's modified Eagle's medium; ELISA: Enzyme-linked immunosorbent assay; EAF: Ethyl acetate-fraction; HBA: Hydrogen bond acceptors; HBD: Hydrogen bond donar; LSD: Least significant difference; RO5: Lipinski's rule of five; MO: Moringa oleifera; HF: n-Hexane-fraction; PDB: Protein Data Bank; RPHPLC: Reversed-phase high-performance liquid chromatography; SF: Solventfraction; TPC: Total phenolic contents

\section{Acknowledgements}

The authors would like to acknowledge the research facility provided by the Institute of Molecular Biology and Biotechnology, The University of Lahore, Main Campus, Lahore, Pakistan.

\section{Authors' contributions}

MZM and FK conceived the study. MH, SJ, and AM helped to design and coordinate the study. FK and MZM carried out the experimental studies. SJ and $\mathrm{AM}$ gave input throughout the study. MZM, MH, and FK analyzed the data. MZM and MH wrote, organized, and revised the manuscript. All authors have read and approved the final manuscript.

\section{Funding}

The current research did not receive any specific grant from funding agencies in the public, commercial, or not-for-profit sectors.

\section{Availability of data and materials}

All data generated or analyzed during this study are included in this published article.

\section{Ethics approval and consent to participate}

Not applicable.

\section{Consent for publication}

Not applicable.

Competing interests

No potential conflict of interest was reported by the author(s).

Received: 25 August 2020 Accepted: 20 January 2021

Published online: 10 February 2021

References

1. Babu KM, Ravindra KB (2015) Bioactive antimicrobial agents for finishing of textiles for health care products. J Text Inst 106:706-717. https://doi.org/10. 1080/00405000.2014.936670

2. Gupta S, Jain R, Kachhwaha S, Kothari SL (2018) Nutritional and medicinal applications of Moringa oleifera Lam. Review current status and future possibilities. J Herb Med 11:1-11. https://doi.org/10.1016/j.hermed.2017.07. 003

3. Rates SMK (2001) Plants as source of drugs. Toxicon 39:603-613. https://doi. org/10.1016/S0041-0101(00)00154-9

4. Seth MK (2003) Trees and their economic importance. Bot Rev 69:321-376 10.1663/0006-8101(2004)069[0321:TATEI]2.0.CO;2

5. Mbikay M (2012) Therapeutic potential of Moringa oleifera leaves in chronic hyperglycemia and dyslipidemia: a review. Front Pharmacol 3:24. https://doi. org/10.3389/fphar.2012.00024

6. Alaklabi A (2015) Genetic diversity of Moringa peregrina species in Saudi Arabia with ITS sequences. Saudi J Biol Sci 22:186-190. https://doi.org/10. 1016/j.sjbs.2014.09.015

7. Anwar F, Latif S, Ashraf M, Gilani AH (2007) Moringa oleifera: a food plant with multiple medicinal uses. Phyther Res 21:17-25. https://doi.org/10.1002/ ptr.2023

8. Pandey A, Pradheep K, Gupta R et al (2011) "Drumstick tree" (Moringa oleifera Lam.): a multipurpose potential species in India. Genet Resour Crop Evol 58:453-460. https://doi.org/10.1007/s10722-010-9629-6

9. Ashfaq M, Basra SMA, Ashfaq U (2012) Moringa: a miracle plant of agroforestry. J Agric Soc Sci 8:115-122 
10. Alhakmani F, Kumar S, Khan S (2013) Estimation of total phenolic content, in-vitro antioxidant and anti-inflammatory activity of flowers of Moringa oleifera. Asian Pac J Trop Biomed 3:623-627. https://doi.org/10.1016/S22211691(13)60126-4

11. Popoola J, Obembe $O O$ (2013) Local knowledge, use pattern and geographical distribution of Moringa oleifera Lam.(Moringaceae) in Nigeria. J Ethnopharmacol 150:682-691. https://doi.org/10.1016/j.jep.2013.09.043

12. Pamok S, Saenphet S, Vinitketkumnuen U, Saenphet K (2012) Antiproliferative effect of Moringa oleifera Lam. and Pseuderanthemum palatiferum (Nees) Radlk extracts on the colon cancer cells. J Med Plant Res 6:139-145. https://doi.org/10.5897/JMPR11.1343

13. Nkukwana T, Muchenje V, Pieterse E et al (2014) Effect of Moringa oleifera leaf meal on growth performance, apparent digestibility, digestive organ size and carcass yield in broiler chickens. Livest Sci 161:139-146. https://doi. org/10.1016/j.livsci.2014.01.001

14. Rahim M, Anwar HM, Alam M (2006) Moringa: an indigenous minor vegetable can play a great role in nutrition and poverty alleviation in north western region of Bangladesh. In: Prospectus for fighting poverty, hunger and malnutrition. international conference on indigenous vegetables and legumes

15. Thurber MD, Fahey JW (2009) Adoption of Moringa oleifera to combat under-nutrition viewed through the lens of the "diffusion of innovations" theory. Ecol Food Nutr 48:212-225. https://doi.org/10.1080/ 03670240902794598

16. Kasolo J, Bimenya G, Ojok L et al (2010) Phytochemicals and uses of Moringa oleifera leaves in Ugandan rural communities. J Med Plant Res 4: 753-757. https://doi.org/10.5897/JMPR10.492

17. Murakami A, Kitazono $Y$, Jiwajinda $S$ et al (1998) Niaziminin, a thiocarbamate from the leaves of Moringa oleifera, holds a strict structural requirement for inhibition of tumor-promoter-induced epstein- barr virus activation. Planta Med 64:319-323. https://doi.org/10.1055/s-2006-957442

18. Kumar NA, Pari L (2004) Antioxidant action of Moringa oleifera Lam. (Drumstick) against antitubercular drugs induced lipid peroxidation in rats. $J$ Med Food 6:255-259. https://doi.org/10.1089/10966200360716670

19. Miyoshi N, Takabayashi S, Osawa T, Nakamura Y (2004) Benzyl isothiocyanate inhibits excessive superoxide generation in inflammatory leukocytes: implication for prevention against inflammation-related carcinogenesis. Carcinogenesis 25:567-575. https://doi.org/10.1093/carcin/ bgh051

20. Chumark $P$, Khunawat $P$, Sanvarinda $Y$ et al (2008) The in vitro and ex vivo antioxidant properties, hypolipidaemic and antiatherosclerotic activities of water extract of Moringa oleifera Lam. leaves. J Ethnopharmacol 116:439446. https://doi.org/10.1016/j.jep.2007.12.010

21. Verma A, Vijayakumar M, Mathela C, Rao C (2009) In vitro and in vivo antioxidant properties of different fractions of Moringa oleifera leaves. Food Chem Toxicol 47:2196-2201. https://doi.org/10.1016/j.fct.2009.06.005

22. Cajuday LA, Pocsidio GL (2010) Effects of Moringa oleifera Lam. (Moringaceae) on the reproduction of male mice (Mus musculus). J Med Plant Res 4:1115-1121

23. Khalafalla MM, Abdellatef $E$, Dafalla $H M$ et al (2010) Active principle from Moringa oleifera Lam leaves effective against two leukemias and a hepatocarcinoma. Afr J Biotechnol 9:8467-8471. https://doi.org/10.5897/ AJB10.996

24. D'Archivio M, Filesi C, Di Benedetto R et al (2007) Polyphenols, dietary sources and bioavailability. Ann Ist Super Sanita 43:348-361

25. Dai J, Mumper RJ (2010) Molecules plant phenolics: extraction, analysis and their antioxidant and anticancer properties. Molecules 15:7313-7352. https://doi.org/10.3390/molecules15107313

26. Prabakaran M, Kim S, Sasireka A et al (2018) Polyphenol composition and antimicrobial activity of various solvent extracts from different plant parts of Moringa oleifera. Food Biosci 26:23-29. https://doi.org/10.1016/j.fbio.2018.09.003

27. Siegel RL, Miller KD, Jemal A (2020) Cancer statistics, 2020. Cancer J Clin 70: 7-30. https://doi.org/10.3322/caac.21590

28. Arbyn M, Weiderpass E, Bruni L et al (2020) Estimates of incidence and mortality of cervical cancer in 2018: a worldwide analysis. Lancet Glob Health 8:e191-e203. https://doi.org/10.1016/S2214-109X(19)30482-6

29. Craig WJ (1997) Phytochemicals: guardians of our health. J Am Diet 5:6-8. https://doi.org/10.1016/S0002-8223(97)00765-7

30. Al-Asmari AK, Albalawi SM, Athar MT, Khan AQ (2015) Moringa oleifera as an anti-cancer agent against breast and colorectal cancer cell lines. PLoS One 10:e0135814. https://doi.org/10.1371/journal.pone.0135814
31. Balamurugan V, Balakrishnan V, Robinson JP, Ramakrishnan M (2014) Anticancer and apoptosis-inducing effects of Moringa concanensis using hepG2 cell lines. Bangladesh J Pharmacol 9:604-609. https://doi.org/10.3329/bjp. v9i4.20481

32. Dalasanur NL, Adhikari R, Singhal J et al (2018) Translational opportunities for broad-spectrum natural phytochemicals and targeted agent combinations in breast cancer. Int J Cancer 142:658-670. https://doi.org/10. 1002/ijc.31085

33. Grace SRS, Chandran G, Chauhan JB (2019) Terpenoids: an activator of "fuelsensing enzyme AMPK" with special emphasis on antidiabetic activity. In: Ozturk M, Hakeem KR (eds) Plant and human health, vol 2. Springer International Publishing, Switzerland, pp 227-244

34. Kaleo I, Gao Q, Liu B et al (2019) Effects of Moringa oleifera leaf extract on growth performance, physiological and immune response, and related immune gene expression of Macrobrachium. Fish Shellfish Immunol 89: 603-613. https://doi.org/10.1016/j.fsi.2019.03.039

35. Nakamura M, Ra J, Jee Y, Kim JS (2017) Impact of different partitioned solvents on chemical composition and bioavailability of Sasa quelpaertensis Nakai leaf extract. J Food Drug Anal 25:316-326. https://doi.org/10.1016/j. jfda.2016.08.006

36. Mosmann T (1983) Rapid colorimetric assay for cellular growth and survival: application to proliferation and cytotoxicity assays. J Immunol Methods 65: 55-63. https://doi.org/10.1016/0022-1759(83)90303-4

37. Teinkela JEM, Noundou XS, Nguemfo EL et al (2018) Biological activities of plant extracts from Ficus elastica and Selaginella vogelli: an antimalarial, antitrypanosomal and cytotoxity evaluation. Saudi J Biol Sci 25:117-122. https://doi.org/10.1016/j.sjbs.2017.07.002

38. Razafintsalama V, Sarter S, Mambu L et al (2013) Antimicrobial activities of Dilobeia thouarsii Roemer and Schulte, a traditional medicinal plant from Madagascar. S Afr J Bot 87:1-3. https://doi.org/10.1016/j.sajb.2013.02.171

39. Bendale Y, Bendale V, Paul S (2017) Evaluation of cytotoxic activity of platinum nanoparticles against normal and cancer cells and its anticancer potential through induction of apoptosis. Integr Med Res 6:141-148. https:// doi.org/10.1016/j.imr.2017.01.006

40. Williams L, Abdi H (2010) Fisher's least significant difference (LSD) test. In: Salkind N (ed) Encyclopedia of research design. Sage Publication Inc., Thousand Oaks, pp 840-853

41. Pettersen EF, Goddard TD, Huang CC et al (2004) UCSF Chimera-a visualization system for exploratory research and analysis. J Comput Chem 25:1605-1612. https://doi.org/10.1002/jcc.20084

42. Mendelsohn LD (2004) ChemDraw 8 ultra, windows and macintosh versions. J Chem Inf Comput Sci 44:2225-2226. https://doi.org/10.1021/ ci040123t

43. Hinchliffe A (1997) CS Chem3D Pro 3.5 and CS MOPAC Pro (Mac and Windows) UK. Electron J Theor Chem 2:215-217. https://doi.org/10.1002/ejtc.54

44. Dallakyan S, Olson AJ (2015) Small-molecule library screening by docking with PyRx. Methods Mol Biol 1263:243-250. https://doi.org/10.1007/978-14939-2269-7_19

45. Brilhante RSN, Sales JA, Pereira VS et al (2007) Research advances on the multiple uses of Moringa oleifera: A sustainable alternative for socially neglected population. Asian Pac J Trop Med 10:621-630. https://doi.org/10. 1016/j.apjtm.2017.07.002

46. Yang RY, Tsou SCS, Lee TC et al (2006) Moringa, a novel plant rich in antioxidants, bioavailable iron, and nutrients. In: Wang M, Sang S, Hwang LS, Ho CT (eds) Herbs: Challenges in Chemistry and Biology. American Chemical Society, Washington, DC, pp 224-239

47. Tiloke C, Phulukdaree A, Chuturgoon AA (2013) The antiproliferative effect of Moringa oleifera crude aqueous leaf extract on cancerous human alveolar epithelial cells. BMC Complement Altern Med 13:226. https://doi. org/10.1186/1472-6882-13-226

48. Al-Sharif I, Remmal A, Aboussekhra A (2013) Eugenol triggers apoptosis in breast cancer cells through E2F1/survivin down-regulation. BMC Cancer 13: 600. https://doi.org/10.1186/1471-2407-13-600

49. Sui L, Dong $Y$, Watanabe $Y$ et al (2005) The inhibitory effect and possible mechanisms of D-allose on cancer cell proliferation. Int J Oncol 27:907-912. https://doi.org/10.3892/ijo.27.4.907

50. Matsuda H, Ochi M, Nagatomo A, Yoshikawa M (2007) Effects of allyl isothiocyanate from horseradish on several experimental gastric lesions in rats. Eur J Pharmacol 56:172-181. https://doi.org/10.1016/j.ejphar.2006.12.040

51. Lacroix M, Toillon R, Leclercq G (2006) p53 and breast cancer, an update. Endocr Relat Cancer 13:293-325. https://doi.org/10.1677/erc.1.01172 
52. Jung IL (2014) Soluble extract from Moringa oleifera leaves with a new anticancer activity. PLoS One 9:e95492. https://doi.org/10.1371/journal.pone. 0095492

53. Huang $W Y$, Cai $Y Z$, Zhang $Y$ (2010) Natural phenolic compounds from medicinal herbs and dietary plants: Potential use for cancer prevention. Nutr Cancer 62:1-20

54. Słoczyńska K, Powroźnik B, Pekala E, Waszkielewicz AM (2014)

Antimutagenic compounds and their possible mechanisms of action. J Appl Genet 55:273-285

55. Munday R, Munday CM (2004) Induction of phase II detoxification enzymes in rats by plant-derived isothiocyanates: comparison of Allyl isothiocyanate with sulforaphane and related compounds. J Agric Food Chem 52:18671871. https://doi.org/10.1021/jf030549s

56. Kou X, Kirberger M, Yang Y, Chen N (2013) Natural products for cancer prevention associated with Nrf2-ARE pathway. Food Sci Human Wellness 2: 22-28. https://doi.org/10.1016/j.fshw.2013.01.001

57. Tian S, Wang J, Li Y et al (2015) The application of in silico drug-likeness predictions in pharmaceutical research. Adv Drug Deliv Rev 86:2-10. https:// doi.org/10.1016/j.addr.2015.01.009

\section{Publisher's Note}

Springer Nature remains neutral with regard to jurisdictional claims in published maps and institutional affiliations.

\section{Submit your manuscript to a SpringerOpen ${ }^{\circ}$ journal and benefit from:}

- Convenient online submission

- Rigorous peer review

- Open access: articles freely available online

High visibility within the field

- Retaining the copyright to your article

Submit your next manuscript at $\boldsymbol{\nabla}$ springeropen.com 